\title{
Building world city Tokyo: Globalization and conflict over urban space
}

\author{
André Sorensen \\ Centre for Urban and Community Studies, Department of Social Science, \\ University of Toronto at Scarborough and Department of Geography and Programme in \\ Planning, University of Toronto \\ (e-mail: sorensen@utsc.utoronto.ca)
}

\begin{abstract}
Japanese policy makers have, since their contact with the colonial powers in the mid 19th century, been acutely aware of the pressures and challenges of national survival in a globalizing world. In this sense, the Japanese experience of modernity has been deeply intertwined with, and is in important ways inseparable from the ongoing processes of globalization during the last century and a half. While their main response was to foster the growth of Japanese industrial, military and diplomatic power, one consistent theme has been the development of the capital city Tokyo as emblem of Japan as a civilized nation, location of national institutions, and center of economic power. This project, however, has long been an arena of considerable conflict between city builders and the residents of central Tokyo. The most recent conflict over the control of urban space in Japan's premier world city emerged in the last few years when major developers lobbied successfully for massive increases in allowable building volumes and heights in special regeneration areas, arguing that without further deregulation Tokyo would lose its competitive position in relation to Shanghai, Hong Kong and Singapore. This paper argues that in Japan an important feature of globalization and international competitive pressures has been their use by urban actors in disputes over the control of urban space, and examines this use of globalization debates in the competition between economic space and life space in Tokyo.
\end{abstract}

\section{Introduction}

\footnotetext{
"Competition between cities is international - to revitalize Tokyo is to revitalize Japan ... if Japan is to prosper in an age of globalization, its cities must attract residents, goods, finance and information from around the world."
}

Mori Building Website, July 2002

One of the key contributions of urban studies to the globalization debate has been the concept of 'world cities'. The research agenda about world cities as first proposed by Friedmann and Wolf (1982), Friedmann's more developed hypothesis (1986) and the monograph by Sassen (1991) which proposed a triumvirate of leading 'global cities' (London, New York, and Tokyo) have 
informed a vast literature on globalization and world cities. The core idea was that a number of global processes including increased integration of world commodities, finished goods and financial markets, and growing interconnection through communications networks were likely to result in a convergence of economic structures, and that this would in turn have similar spatial and social impacts in diverse world cities. Looking at the leading 'global cities,' Sassen (1991: 4) found that indeed such parallel changes in economic base, spatial organization and social structure were occurring, and strongly asserted the primary role of global processes in those changes.

Subsequent research put more emphasis on the role of national and local actors and institutions in mediating, contesting, and shaping the particular products of economic changes in particular cities (Goetz and Clarke 1993; Knox and Taylor 1995; Eade 1997). The prevailing interpretation today is that while global forces are generally the more powerful, and affect all major cities depending on their degree of interconnectedness with the world economy, local histories and institutions do influence outcomes in particular places, which are diverse (e.g., Pacione 2001: 8).

Tokyo has played a lead role in globalization debates from the beginning. Sassen (1991) stressed the importance of Tokyo as a key node in the world economic system alongside London and New York, and a large body of work discerned a range of globalization induced changes to the Tokyo spaceeconomy (Rimmer 1986; Douglass 1988; Fujita 1991; Douglass 1993). In particular, Tokyo's emergence as a key global command and control center, the increasing importance of financial, insurance and real estate industries in its economy and their consequent demand for central city office space were seen as having major impacts on the space economy of central city areas (Sassen 1991). Fujita (1991) argues that Tokyo's development into a world city is primarily a result of its flexible manufacturing prowess, which captured a major share of world markets, allowed the creation of vast trade surpluses, and encouraged the growth of financial services industries. That in turn increased the capital's dominance over the Japanese economy as well as intensified competition for space in central areas, exacerbating housing problems and other social tensions. Others described the adverse social impacts of urban restructuring including upward spiraling land prices and rents resulting from buoyant markets for office space, the displacement of population from central city areas, the uprooting of long-standing communities, and lengthening commutes (Douglass 1993: 88). He suggests that while economic growth had certainly brought Japanese people higher incomes and greater consumption, urban quality of life had not improved, and may even have worsened (Douglass 1993: 88). Machimura (1992, 1998) stresses the political conflicts arising from urban restructuring, and argues that the concept of world city has been used symbolically as a political level in domestic political conflicts over urban space.

Recent work has contributed case studies of specific globalization-related changes, such as the development of the waterfront subcenter on reclaimed land in Tokyo Bay, which was developed explicitly to advance Tokyo's world city ambitions (Saito 2003). Saito examines the political dynamics behind the subcenter project, and finds that the main player was the Tokyo Metropolitan Government, which saw its role as fostering Tokyo's emergence as a premier world city by creating an advantageous location for high tech office towers and high amenity living space. Saito's fascinating play-by-play description of 
the evolving political dynamics behind the project provides a useful glimpse into Japanese policymaking. In contrast to much of the Anglo-American literature on globalization and world cities, which sees market forces as the overwhelmingly dominant force behind spatial restructuring in world cities, in Saito's examination of the waterfront subcenter it was the State that dominated the process, not private enterprise. Following Hill and Kim (2000) he explains this strong role of the state as a product of Japan's history of "developmental state" policies.

In the present context his stress on the importance of the developmental state is significant. While there has been an extended debate among students of Japanese political economy of the relative importance of the state bureaucracy, political parties, and big business (see, e.g., Johnson 1982; Deyo 1987; Gao 1997), no one would argue that Japan is a liberal market economy in the pattern of the United States. Here it is not necessary to take sides in the debate over the precise degree of credit for Japanese economic success to assign the Japanese bureaucracy. It is important, however, to understand that Japan had a much different experience of modernization, industrialization and urbanization than any of the other developed countries, and that this contributed to the development of a highly distinctive planning culture. The Japanese leadership always saw the building of a strong State as the primary national project - a project to which the people should subordinate themselves - and which was commonly cast in a framework of fierce international competition in which Japan played the role of outsider catching up. While there were dramatic changes over the course of the $20^{\text {th }}$ century, the focus of resources on developmental goals rather than public welfare has proven highly enduring, as shown below.

Far from the competitive pressures of globalization being a phenomenon new to the 1980s, therefore, in Japan they have been a driving force behind national policymaking for at least a century. In this competitive world environment, the Japanese leadership consistently put national development and international stature ahead of private welfare or even collective quality of life. This makes it somewhat difficult to distinguish a particular period during which globalization pressures begin to impact Japanese public policy. While it is often suggested that deregulation and the hollowing out of the welfare state are prominent manifestations of globalization, in Japan the welfare state was always thin, the state sector small, and as shown below, regulation of urban development weak. The priority was economic development, and urban planning was carried out primarily to foster that growth, not to help create or maintain amenities or improve the quality of life in urban areas (see Sorensen 2002). In Friedmann's (1988) terms, the priority was always "economic space" not "life space."

Friedmann's concept of the conflict between "life space" and "economic space" is particularly helpful for understanding Tokyo's restructuring conflicts. Tokyo was already a giant city of over a million during the feudal era two centuries ago, and the current structure of land uses is still strongly influenced by its long urban history (see Cybriwsky 1998; Sorensen 2002). Urban restructuring and redevelopment in the early postwar period was carried out primarily along major new arterial roads and at nodes in the public transport system. This bypassed many older traditional neighborhoods that are characterized by extremely fragmented land ownership patterns and narrow roads inherited from earlier periods. Apart from the real difficulty of 
land assembly for redevelopment in such areas, a building code regulation first passed in 1919 ties allowable building height to a slant plane drawn from the opposite side of the road on which a property fronts (Sorensen 2002: 116). Throughout Tokyo, but particularly in areas of narrow roads and small lots, this regulation severely limits the height of buildings and development capacity (Onishi 1994). It also helped to protect from redevelopment many inner city districts, which commonly maintained many of the characteristic features of traditional Japanese cities; narrow roads, small neighborhood commercial centers (shotengai) of family run shop-houses with the shop at ground level and residence above, strong neighborhood organizations which managed the local shrine and festival, recycling collection, park maintenance and fire patrol among other functions (Bestor 1989). The central area of Tokyo thus retained many close-knit residential communities, which were geographically distinct and separated from the main areas of modern highrise development. As shown below, however, such areas of "life space" have come under repeated pressure for profitable redevelopment to "economic space" since the 1960 s.

While this has been a long-term struggle between the forces of economic change and community stability, however, it is only in the 1980s and 1990s that the language of globalization and world cities began to be used to legitimize and explain these conflicts, as shown below. Section 2 outlines the weak planning system of the rapid growth period in the 1950s and 1960s, and describes several key planning protections won by progressive political forces and social movements in the 1960s and 1970s. Section 3 outlines the swings from deregulation in the 1980 s to re-regulation after the bubble to the most recent period of deregulation from the late 1990s. Section 4 summarizes the main findings.

\section{Shifting the balance between developers and communities, 1960s-1970s}

During the rapid economic growth period of the 1950s and 1960s Japan had an extremely weak system of urban land planning and development control. This assertion seems to contradict the widely held perception of a "Japan Inc." that was a highly efficient, technocratic, well-planned developmental state which effectively mobilized national resources in pursuit of economic growth (Johnson 1982). In fact, while the latter description is certainly an oversimplification of the case (for other interpretations see, e.g., Muramatsu and Krauss 1987; Calder 1988), it is widely agreed that during the rapid growth period an "iron triangle" of Liberal Democratic Party (LDP), central government bureaucracy, and big business worked effectively to mobilize available national resources, and produced spectacular economic growth. At the same time, this focus of the nation's resources on industrial development and capital formation resulted in ongoing shortages of investment in social overhead capital. As Honjo put it: "The conditions under which Japan developed were so severe that it was impossible to do more than the bare minimum. The accumulated capital was always mobilized for investment in productive sectors, and an urban development policy focused on infrastructure was promoted ... The housing supply was left to the private sector, and only during emergencies such as natural disasters were public measures initiated or expanded" (Honjo 1984: 28). The role of city planning was seen as 
the supply of infrastructure for economic growth: highways, ports and airports, industrial water supply, serviced industrial sites, and low-cost public housing for the workers who migrated in their millions to the cities (Morimura 1994). Little money was spent on residential areas and low priority was put on investment in the more discretionary public goods such as parks, local roads or sidewalks. Instead of creating a system to regulate private urban development, the state provided a range of basic infrastructure such as water supply and arterial roads, while encouraging private investors to provide other needed urban investment such as in electrical generation, commuter railways, and housing development.

The weak planning system was thus a result not of a lack of state capacity, as in many developing countries today, but of a narrowly focused urban policy which prioritized economic development. The main planning tool was a weak zoning system, with only four zones, residential commercial, industrial and quasi-industrial. Housing could still be built within industrial and commercial zones, and small-scale industry within residential and commercial zones. Within zoned areas land development was as-of-right, with no requirements for basic urban infrastructure before land development, no subdivision control, nor any minimum housing standards. The result was extremely rapid growth of haphazard un-serviced sprawl combining housing, commercial and industrial uses at high densities. In primarily residential areas much housing was built along narrow, unpaved private roads, and large areas were built up without municipal sewers, parks, piped gas supply or even sidewalks (Sorensen 2001a).

This weak planning system was very much the product of strong central control. This is partly because local governments are highly dependent on grants from the central government, and that funding was tightly focused on the developmental priorities noted above. It is even more a result, however, of the fact that planning law was written and interpreted by central government ministries, and local governments had no legal authority to go beyond the parameters set by national legislation. For example, because the national government had set no minimum housing standards, minimum plot sizes, or minimum infrastructure requirements for land development, municipal ordinances that attempted to introduce such measures could not be legally enforced, and local governments frequently lost court challenges to them (Jain 1991). In this way central government effectively limited the planning tools available to local governments.

While in the early post-war period there was a broad agreement that economic growth was a top priority, the success of that project created other pressing problems that effectively shattered the consensus around growth during the 1960s. Large-scale development of heavy and chemical industries intermixed with or in close proximity to residential and commercial areas, combined with almost non-existent pollution controls, resulted in a severe environmental crisis. Pollution of air, water and food supplies was directly related to the spread of environmental diseases, and hundreds died, thousands suffered debilitating and painful diseases or were born deformed, and hundreds of thousands suffered from asthma and other chronic pollutionrelated ailments (see Huddle, et al. 1975; McKean 1981; Ui 1992; George 2001). Eventually, large numbers of local environmental protest movements developed to lobby for better pollution control regulations and against industrial development (McKean 1981; Upham 1987). 
This conflict extended also to urban planning policy. Krauss and Simcock (1980: 196) suggest that there was an "explosion of protest in urban and suburban areas" against industrial plants and highway interchanges, and demanding that local governments provide essential services such as sewers, parks and sidewalks. As Samuels (1983: 190) described it, "The left came to power by convincing enough of the electorate that the conservative central government and their allies in the localities were responsible for the pollution, the lack of social programs, and the support of business interests at the expense of residents." The growing political strength of progressives in both local and central government elections scared the ruling LDP into passing new city planning legislation in 1968 (Calder 1988: 405). The New City Planning Law of 1968 was the first major post-war swing of the pendulum towards greater emphasis of urban planning on urban quality of life and tighter regulation of development, and it generated high hopes that local governments would finally have the tools to be able to control land development and improve urban environments.

Although the new planning system encountered serious difficulties in managing urban growth on the fringe (see Nakai 1988; Hebbert 1994; Sorensen 1999; Sorensen 2001a), the new zoning system did have a significant impact on development in existing built-up areas. The key factor was the introduction of the Exclusive Residential Zone \#1, which was the first land use zone meaningfully restricting land uses. In the new zone not only was land use restricted to residential uses and related compatible land uses (e.g., churches, small-scale retail), but a strictly enforced absolute height limit of 10 meters was also imposed. The height limit was important. The Japanese building code had since the prewar period maintained a strictly enforced absolute height limit of 30 meters on all buildings because of concerns about earthquakes. However, the limit was abolished by the 1970 revision to the Building Standards Law because of dramatic improvements in engineering technology using steel reinforced concrete. As a result, extensive low- and medium-rise areas were suddenly ripe for redevelopment into higher-rise buildings, and the 1970s saw a rush to inner-city condominium building, the so-called "manshon boom."

The condominium boom created severe conflicts in many areas, in part because the high-rise buildings brought with them increased local congestion and noise, but even more because they almost always blocked direct sunlight to neighboring houses for part of the day. In Japan direct sunlight is an essential aspect of residential quality of life, houses have long been routinely oriented towards the sun, and an important part of housewives' daily routine - even today - is to hang bedding out in the sun to air it out. Where buildings block the sun, residential amenity is permanently impaired. In residential areas throughout Tokyo local citizens' groups organized to oppose the building of high-rise apartment buildings which blocked the sunlight from surrounding houses (Ishizuka and Ishida 1988: 30).

As the only land use zone that retained any height control function was the Exclusive Residential Zone \#1, designation of such zones became a highly contested process, as it effectively barred redevelopment to high rises. In the early 1970s, the Tokyo Prefecture and most Tokyo wards were controlled by progressive administrations, and in many cases the rezoning to the new zoning system gave priority to the protection of existing traditional residential communities. In 1972, again responding to electoral pressure and increasingly vocal citizen movements, the government passed an amendment to the 
Building Standards Law that allowed the creation of Height Control Zones with a maximum building height of 10 meters that could be designated over other land use zones. Such height control zones were widely designated by sympathetic ward governments to protect residential areas throughout central Tokyo and became an increasing source of conflict later, as discussed below.

A third factor that served to protect low-rise residential areas from highrise redevelopment was directly the result of the activities of the citizen movements of the early 1970s. A Tokyo-wide organization of sunshine rights groups won a series of court cases against developers of high-rise buildings, forcing them to compensate the neighbors they had deprived of light. In 1972, the Supreme Court determined that Article 25 of the constitution, which guarantees "minimum standards of wholesome and cultural living," protected the right to sunshine, and that infringements of sunshine rights were liable for damages (McKean 1981: 113). Then in 1973 the citizens' movement drafted and presented their own proposal for a sunlight protection ordinance (Hiatari Jôrei) to the Tokyo Metropolitan Government. As Ishida and Ishizuka suggest: "This was an epochal development in the citizens' movement in that it progressed from simply opposing things to actively proposing policies" (Ishizuka and Ishida 1988: 30). Through the 1970s a large number of sunshine rights cases were won against offending builders and even against the government in the case of an elevated expressway.

In this context the government worked quickly to revise the building regulations. The level of uncertainty about what was permissible and what would incur liability to pay damages was high enough that builders ran an unacceptably high risk of losing court battles with neighbors, even where they had complied with existing regulations. The Ministry of Construction (MoC) drafted a revision to the building standards law that included many of the proposals of the citizens' movement, and those revisions came into effect in 1976. The revision required all local governments to draft their own sunshine standards that specified the minimum hours of unimpeded sunlight cast to the north of new buildings on the winter solstice when the sun is at its lowest.

These three changes, the creation of Exclusive Residential \#1 zones, the ad hoc height control zones, and the sunlight preservation regulations, significantly changed the balance of power between urban residents and the development industry, and permitted local governments to increase their controls over development in existing built up areas. For the first time residential neighborhoods had some leverage to protect themselves from redevelopment initiatives. That this new regime really did represent a significant shift in the power balance is suggested by the fact that from the early 1980s the central government, urged on by the development industry, started to work hard to weaken these regulations to permit more redevelopment in central Tokyo.

\section{From deregulation in the 1980 s to re-regulation in the 1990 s and incentives in 2000}

In the early 1980s the urban policy climate shifted abruptly. The new Prime Minister Nakasone, inspired by the neoliberal policies of Thatcher and Reagan, promoted policies of deregulation, privatization and fiscal retrenchment. A key rationale for deregulation was to enhance Japan's international economic competitiveness, and urban planning deregulation 
efforts were increasingly cast in terms of the economic importance of World City Tokyo in a globalizing world. At the Tokyo Metropolitan Government level the conservative administration of governor Suzuki strongly supported a "world city" strategy for Tokyo's glorious future as an international city (Tokyo Metropolitan Government 1987), although Machimura (1998) argues that this use of the term was primarily symbolic, designed to impress and gain support for the deregulation program.

Deregulation of city planning regulations was carried out throughout the 1980s. While Nakasone's neoliberal agenda closely followed those of Thatcher and Reagan, urban policies were explicitly oriented towards the remodeling of Tokyo into a competitive World City. Hence, a central and early part of Nakasone's deregulation campaign focused on encouraging redevelopment in central Tokyo. For example, one of the first actions of the Nakasone government upon taking office in 1982 was to direct the MoC to review the zoning of all the areas in central Tokyo that were zoned Exclusive Residential \#1. The idea was to rezone them to Exclusive Residential \#2 in which high-rise buildings can be built, so that Tokyo could begin to look more like New York (Hebbert and Nakai 1988: 386; Miyao 1991: 132). Then in March of 1983 the Ministry of Construction ordered all local governments to encourage development by relaxing regulations. Specifically, they were to increase the ratio of building volume to lot size, rezone residential zones to commercial, and weaken various restrictions on urban fringe land development (Hayakawa and Hirayama 1991: 153). The central government also strongly pressured local governments to weaken or abolish their non-statutory "Development Manuals" which specified required levels of contribution to public infrastructure to get a development permit.

The relatively low intensity of land use in central Tokyo compared to other developed country major cities was seen as a problem. For example, the Tsukuba National University economist Takahiro Miyao argued that planning restrictions limiting the height of buildings in much of central Tokyo were a key urban problem because they made it difficult to redevelop central city areas to more intensive uses such as high-rise condominiums. He argued for further deregulation, suggesting that the vigor of the private sector needed to be freed from excessive planning regulations in order to "take full advantage of the vitality in the metropolitan regions" (Miyao 1987: 58-9). Specifically, deregulation should ensure that "excessive restrictions of the residential area development guidelines by local municipalities would be corrected" (Miyao 1987: 59).

Even though most ward governments successfully resisted pressure to abolish the Exclusive Residential \#1 Zones in central Tokyo, the list of national planning deregulations was long, and these had powerful impacts on urban redevelopment patterns (Hayakawa and Hirayama 1991; Otake 1993; Inamoto 1998). One particularly important new planning measure for central area redevelopment was an incentive to provide more inner city public space. Modeled after New York's Plaza Bonus system, it rewarded developers with extra height and floor space allowances in return for the provision of public open space or plazas at ground level. This was a logical measure in a city as crowded as Tokyo, with a shortage of public open space, particularly in core areas. Developers were eager to use it. Even though there were no absolute height restrictions in much of central Tokyo, floor area ratios, slant plane restrictions and sunlight ordinances still put serious limits on building 
heights and volumes. The plaza bonus measure allowed them to negotiate significant increases in height and bulk over and above those limits.

At the Tokyo Metropolitan Government level the conservative administration of governor Suzuki actively supported its own vision of polycentric development within the greater Tokyo area (Sorensen 2001b). Of the various subcenters, the most closely related to the world city project was the waterfront subcenter to be built on reclaimed land in Tokyo Bay (Saito 2001). Promoted initially as Tokyo Teleport Town, which was planned to function as Japan's main international communications gateway, the concept was to provide a major new supply of high quality office space in a high tech cluster. Other major infrastructure projects pursued by the Suzuki administration such as new subway lines, water supply projects, wastewater treatment plants, and garbage incinerators were also designed to facilitate central area redevelopment and intensification.

Planning deregulation, fiscal stimuli, and infrastructure spending were successful beyond expectations. In the second half of the 1980s the Japanese economy boomed and redevelopment of central Tokyo proceeded apace. While at the time the boom seemed very impressive, and "triumphalist" predictions abounded that Japanese economic output would soon surpass that of the US, in retrospect the boom was an unmitigated disaster. Land prices soared, first in central Tokyo and then in the rest of the country, resulting in sharp increases in inequality as those with land assets gained and those without found themselves ever farther away from owning their own home (Tachibanaki 1992; Noguchi and Poterba 1994). The frenzy of real estate investment amid continuously rising land prices created powerful incentives for the highrise redevelopment of existing low-rise inner city residential areas.

While there is no doubt that in many cases small inner city landowners were happy to sell their property at very high prices and move out to the suburbs, in many other cases owners wished to stay in communities where they had long ties. Even more reluctant to move were tenants who often had low rents and legal protection against eviction. In cases where owners were reluctant to sell, or tenants preferred not to move, land assembly became the work of "land sharks" (jiageya), or real estate gangsters who used intimidation, threats and violence to encourage people to leave (Hayakawa and Hirayama 1991: 156; Cybriwsky 1993: 140). Another tactic that was particularly harmful to inner city communities was the buying up and closure of privately operated public baths that functioned both as an essential public facility (in areas where many houses had no baths of their own) and as a key neighborhood meeting place. The number of public baths declined from 22,650 in 1964 to 39 by the end of 1986 (Douglass 1993: 98). There is no doubt that the real estate investment explosion of the 1980s greatly heightened conflict over space in central Tokyo, and that deregulation weakened the ability of communities to maintain life space against the encroachment of economic space. In order to increase profits to real estate developers, inner city communities were destroyed. Housing problems increased sharply, particularly for the very poor (Kodama 1990; Watanabe 1992; Oizumi 1994). Unfortunately, the boom also seriously damaged the Japanese economy. When the bubble burst, the nation's financial system almost collapsed under the weight of bad real estate loans, and the country has suffered economic stagnation since 1991 up to the present.

By the late 1980s there was increasing public pressure to address the land inflation crisis. The ongoing process of deregulation and government down- 
sizing was, at least temporarily, derailed, and the committee in charge of planning and land deregulation in particular was forced to do an about face and start promoting strengthened land development and speculation controls as detailed by Otake (1993). In the late 1980s and early 1990s there were several moves in the direction of re-regulation of land development, especially the Basic Land Law of 1989. The Law declared that: "First, public welfare should be given priority over private profit in the ownership and use of land. Second, land should be used in a proper and orderly fashion. Third, land should not be an object of speculation. Fourth, landowners should return a part of their profits to the public through imposition" (Oizumi 1994: 210).

Another step was a significant strengthening of the City Planning Law, including provisions for Master Planning and improved zoning regulations among others (Watanabe 1992; Oizumi 1994: 211; Sorensen 2002: 302). While there has been considerable debate about the effectiveness of many of these measures, it is clear that the excess of the bubble economy period had effectively undermined the political viability of the deregulation argument. As a result, the pendulum swung again in the early 1990s in favor of greater public and governmental support for stronger planning and the tighter regulation of land development.

More recently, the extended recession of the 1990s has again tipped the political advantage in favor of the property development industry. In particular, the financial system has been on the brink of collapse because of massive bad loans resulting from real estate deals during the bubble, the crash of equities values, and the continuing decline in Japanese land prices since 1991. Hence, government policy has given priority to stabilizing the financial system. This has included major bailouts to the banks and huge spending on infrastructure projects to inject funds into the construction and development industries.

Perhaps most important in the present context have been moves to deregulate the property development industry to make land development profitable once again to compensate for bubble-related losses. During the 1990 s a series of changes by the central government to the Building Standards Law have allowed significant increases in allowable building heights and volumes in order to make urban redevelopment more profitable. The most recent change results from the passage in April of 2002 of the Special Urban Regeneration Act by the Koizumi government. This act established an urban regeneration office within the national cabinet. This office has the authority to designate Urban Regeneration Areas in which greatly weakened development regulations will apply and FAR bonus systems such as for Plazas can be permitted directly by central government instead of requiring local government consultation. This avoids the head-on confrontation with local governments over rezoning that proved so problematic in the 1980s. The main advocates of these measures have been the largest property development companies that stand to profit considerably from floor area bonuses and deregulation. These companies have argued strongly that competition from Singapore, Shanghai and Hong Kong requires urgent measures if Tokyo is to remain competitive in the global property market. The main opponents have been local governments and local communities that have seen a significant erosion of local legal powers to regulate inner city redevelopment.

By giving cabinet authority to designate regeneration areas, the central government has made it much easier and faster to grant approval for huge 
FAR bonuses for redevelopment of inner city sites into high-rise global space. This sidesteps the protests of local residents and the sometimes extended processes of public consultation demanded by local governments. The government hopes this will contribute to the high-rise redevelopment of the low-rise areas of inner Tokyo, provide more housing and office space to allow Tokyo to compete better with other world cities, and restore land development companies to profitability.

\section{Conclusions}

There are different ways of interpreting this history. It could be argued that Tokyo provides a classic case of globalization impacts on urban change. The last two decades have seen the unremitting encroachment of life space by economic space, repeatedly sponsored and encouraged by the central government in the name of building a competitive global city. While Japan's developmental state history makes it distinctive in many aspects of its relationships between State, society and market, it is possible to argue that in Japan one important impact of global economic integration and increased international competition has been increased pressure for the redevelopment of traditional residential areas to high-rise office space. A significant consequence has been the weakening of the planning protections inner-city communities had gained during the struggles of the 1970s.

On the other hand, it can also be argued that the concept of globalization in Japanese political discourse is primarily used a strategic tool to gain political advantage. In this sense, the stress on the need to compete with Shanghai and Hong Kong in the lobbying by property developers for weaker development regulations, more ad hoc FAR bonuses and greater public subsidy of infrastructure improvements can be interpreted as mere opportunism. The fact that the development industry has gained significant benefits from their use of the globalization threats does, however, indicate the continuing political usefulness of globalization/world city discourses. In the Japanese case, therefore, globalization does not seem to influence urban change primarily through foreign direct investment in urban (re)development, but by providing a convincing political argument for the weakening of local planning controls and participation processes.

What is clear is that since the high point of citizen mobilization over environmental issues and progressive control of local governments in the mid 1970s, communities in inner city areas have, on the whole, been fighting a losing battle against a resurgent property development industry that seeks to redevelop inner city neighborhoods into high-rise towers. Issues of quality of life and urban livability continue to be given short shrift, communities in inner city Tokyo continue to feel pressure, and life space continues to be redeveloped as economic space.

\section{References}

Bestor TC (1989) Neighborhood Tokyo. Stanford University Press, Stanford

Calder KE (1988) Crisis and compensation: public policy and political stability in Japan, 19491986. Princeton University Press, Princeton 
Cybriwsky R (1993) Tokyo. Cities 10(1):2-11

Cybriwsky R (1998) Tokyo: The changing profile of an urban giant. Wiley, Chichester

Deyo FC (ed) (1987) The political economy of the new asian industrialism. Cornell University Press, Ithaca

Douglass M (1988) The transnationalization of urbanization in Japan. International Journal of Urban and Regional Research 12(3):425-454

Douglass M (1993) The 'New' Tokyo story: Restructuring space and the struggle for place in a world city. In: Fujita K, Hill RC (eds) Japanese cities in the world economy. Temple University Press, Philadelphia, pp 83-119

Eade J (1997) Living in the global city: Globalization as local process. Routledge, London

Friedmann J (1986) The world city hypothesis. Development and Change 17:69-84

Friedmann J (1988) Life space and economic space: Contradictions in regional planning, in life space and economic space: Essays in third world planning. Transaction Books, New Brunswick, N.J, pp 93-108

Friedmann J, Wolff G (1982) World city formation: An agenda for research and action. International Journal of Urban and Regional Research 6(3):309-344

Fujita K (1991) A world city and flexible specialization: Restructuring of the Tokyo metropolis. International Journal of Urban and Regional Research 15(1):269-284

Gao B (1997) Economic ideology and Japanese industrial policy: Developmentalism from 1931 to 1965. Cambridge University Press, New York

George TS (2001) Minamata: Pollution and the struggle for democracy. Harvard University Press, Cambridge

Goetz EG, Clarke SE (eds) (1993) The new localism: Comparative urban politics in a global era. Sage, Newbury Park

Hayakawa K, Hirayama Y (1991) The impact of the minkatsu policy on Japanese housing and land use. Environment and Planning D: Society and Space 9:151-164

Hebbert M (1994) Sen-biki amidst Desakota: Urban sprawl and urban planning in Japan. In: Shapira P, Masser I, Edgington DW (eds) Planning for cities and regions in Japan. Liverpool University Press, Liverpool, pp 70-91

Hebbert M, Nakai N (1988) Deregulation of Japanese planning. Town Planning Review 59(4):383-395

Hill RC, Kim JW (2000) Global cities and developmental states: New York, Tokyo and Seoul. Urban Studies 37(12):2167-2195

Honjo M (1984) Key issues of urban development and land management policies in Asian developing countries. In: Honjo M, Inoue T (eds) Urban development policies and land management: Japan and Asia. City of Nagoya, Nagoya, pp 15-35

Huddle N, Reich M, Stiskin N (1975) Island of dreams. Autumn Press, New York

Inamoto Y (1998) The problem of land use and land prices. In: Banno J (ed) The political economy of Japanese society, vol. 2, Internationalization and domestic issues. Oxford University Press, Oxford, pp 229-264

Ishizuka H, Ishida Y (1988) Tokyo, the metropolis of Japan and its urban development. In: Ishizuka H, Ishida Y (eds) Tokyo: Urban growth and planning 1868-1988. Center for Urban Studies 3-35, Tokyo

Jain PC (1991) Green politics and citizens power in Japan. The Zushi Movement. Asian Survey 31(5):559-575

Johnson C (1982) MITI and the Japanese miracle, the growth of industrial policy, 1925-1975. Stanford University Press, Stanford

Knox P, Taylor PJ (eds) (1995) World cities in a world system. Cambridge University Press, New York

Kodama T (1990) The new aspects of housing problems in Tokyo. Osaka City University Economic Review 25(1):1-12

Machimura T (1992) The urban restructuring process in Tokyo in the 1980s: Transforming Tokyo into a world city. International Journal of Urban and Regional Research 16:114-128

Machimura T (1998) Symbolic use of globalization in urban politics in Tokyo. International Journal of Urban and Regional Research 22(2):183-194

McKean M (1981) Environmental protest and citizen politics in Japan. University of California Press, Berkeley

Miyao T (1987) Japan's urban policy. Japanese Economic Studies 15(4):52-66 
Miyao T (1991) Japan's urban economy and land policy. Annals of the American Academy of Political and Social Science (513 January):130-138

Morimura M (1994) Change in the Japanese urban planning priorities and the response of urban planners 1960-90. In: University of Tokyo Dept. of Urban Engineering (ed) Contemporary studies in urban environmental management in Japan. Kajima Institute Publishing 8-24, Tokyo

Muramatsu M, Krauss E (1987) The conservative policy line and the development of patterned pluralism. In: Yamamura K, Yasukichi Y (eds) The political economy of Japan, vol. I. The domestic transformation. Stanford University Press, Stanford, pp 516-554

Nakai N (1988) Urbanization promotion and control in metropolitan Japan. Planning Perspectives 3:197-216

Noguchi Y, Poterba JM (eds) (1994) Housing markets in the United States and Japan. University of Chicago Press, Chicago and London

Oizumi E (1994) Property finance in Japan: expansion and collapse of the bubble economy. Environment and Planning A 26(2):199-213

Onishi T (1994) A capacity approach for sustainable urban development: An empirical study. Regional Studies 28(1):39-51

Otake H (1993) The rise and retreat of a neoliberal reform: Controversies over land use policy. In: Allinson G, Sone Y (eds) Political dynamics in contemporary Japan. Cornell University Press, Ithaca, pp 242-263

Pacione M (2001) Urban geography: A global perspective. Routledge, London

Rimmer P (1986) Japan's world cities: Tokyo, Osaka, Nagoya or Tokaido Megalopolis. Development and Change 17:121-158

Saito A (2003) World city formation in capitalist developmental state: Tokyo and the waterfront sub-centre project. Urban Studies 40(2):283-308

Samuels RJ (1983) The politics of regional policy in Japan: Localities incorporated? Princeton University Press, Princeton, New Jersey

Sassen S (1991) The global city: New York, London, Tokyo. Princeton University Press, Princeton, New Jersey

Sorensen A (1999) Land readjustment, urban planning and urban sprawl in the Tokyo metropolitan area. Urban Studies 36(13):2333-2360

Sorensen A (2001a) Building suburbs in Japan: Continuous unplanned change on the urban fringe. Town Planning Review 72(3):247-273

Sorensen A (2001b) Subcentres and satellite cities: Tokyo's 20th century experience of planned polycentrism. International Journal of Planning Studies 6(1):9-32

Sorensen A (2002) The making of urban Japan: Cities and planning from edo to the 21st century. Routledge, London

Tachibanaki T (1992) Higher land prices as a cause of increasing inequality: Changes in wealth distribution and socio-economic effects. In: Haley JO, Yamamura K (eds) Land issues in Japan: A policy failure? Society for Japanese Studies, Seattle, pp 175-194

Ui J (ed) (1992) Industrial pollution in Japan. United Nations University Press, Tokyo

Upham FK (1987) Law and social change in postwar Japan. Harvard University Press, Cambridge

Watanabe Y (1992) The new phase of Japan's land, housing, and pollution problems. Japanese Economic Studies 20(4):30-68 
Copyright $\odot 2003$ EBSCO Publishing 